\title{
Effect of Crop and Non Crop Mulch Management under Varying Moisture Regimes on the Growth and Yield of Zero Tillage Potato in Rain-fed Low Land Rice Eco System
}

\author{
P. Chettri ${ }^{1^{*}}$ and S.B. Goswami ${ }^{2}$ \\ ${ }^{1}$ Department of Agriculture, The Neotia University, Sarisa, 24 Parganas (S), \\ West Bengal, India \\ ${ }^{2}$ Department of Agronomy, Bidhan Chandra Krishi Viswavidyalaya, Mohanpur, Nadia, \\ West Bengal, India \\ *Corresponding author
}

\section{A B S T R A C T}

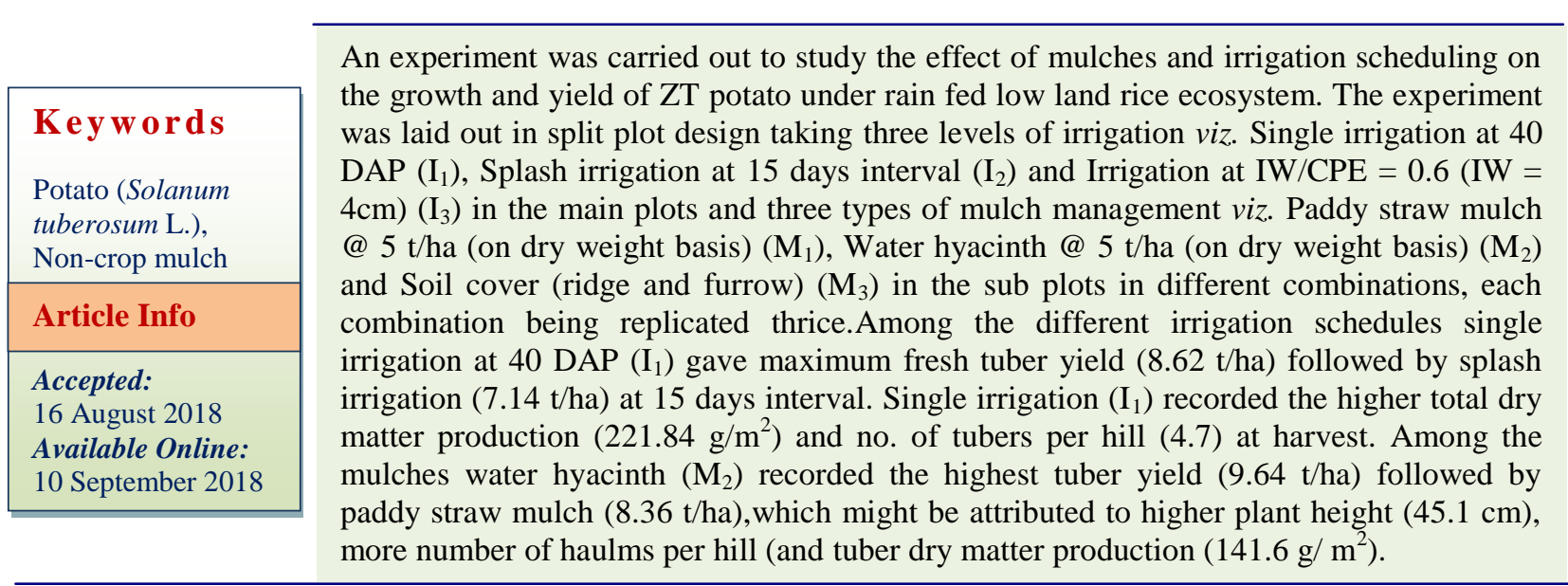

\section{Introduction}

Potato (Solanum tuberosum L.), a nourishing and wholesome food plays a pivotal role in the farm economy. The history of potato in the continent is a proof of the fact that whenever there has been a scarcity of food grains, potato has come to the rescue of the people. It can provide both food and nutritional security in the future as it is one of the most productive crops known to man. Potato gives high yields and its nutrition value is very high. India's population is growing at $1.9 \%$ annually and it is being estimated that due to this alarming rate of growth of population, there will be an acute shortage of $45 \mathrm{mt}$ of food grain by 2030 . At present $60 \%$ of the country's area is under cultivation and there is limited scope to further increase the area. There are also very few ways to increase the production of cereals. A time has, therefore come now to look into the alternate crops to meet up the needs. The 
present vulnerability of national food budgets to the vagaries of weather arise from our dependence on a few crops for our daily bread. Potato can help to widen the food supply base and thereby help to minimize the risk of serious food shortage in the tropics and sub tropics (Shekhawat, 1999). India accounts for around $16 \%$ of the world's human population but it has only around $4 \%$ of the water resources. Even on full exploitation of the irrigation potential only about $50 \%$ of the country's cultivated area will be irrigated. Irrigation is one of the most important aspects with regards to increasing crop production. However it does not mean that application of irrigation water at any stage or any time will increase the yield of the crop. For efficient water management, scheduling of irrigation would be the best. Irrigation scheduling may be done in many ways such as the critical growth stage of the crop, the irrigation water is to cumulative pan evaporation ratio (IW: $\mathrm{CPE}$ ), soil moisture tension etc. The irrigation water should thus be used in such a way that the maximum tuber yield per unit of water used by the crop is achieved. This is the reason why the uses of mulch materials are gaining momentum. Mulching not only helps to minimize irrigation requirements but it also suppresses the weed population. Keeping these things in mind an experiment was conducted to study the growth and yield of zero tillage potato as influenced by crop and non-crop mulch management under varying moisture regimes in rain-fed low land rice eco system.

\section{Materials and Methods}

The experiment was conducted at Central Research (C.R.) Farm, Gayeshpur, Bidhan Chandra Krishi Viswavidyalaya, Nadia, West Bengal, during the Rabi season from November 2006 to February 2007, to study the growth and yield of zero tillage potato as influenced by crop and non-crop mulch management under varying moisture regimes in rain-fed low land rice eco system. The farm is situated at $23^{\circ} \mathrm{N}$ latitude and $89^{\circ} \mathrm{E}$ longitudes with an average altitude of $9.75 \mathrm{~m}$ above MSL. The experiment was conducted during Rabi season from November 2006 to February 2007. A total of 27 plots, each of size $4 \mathrm{~m} \mathrm{X} 3 \mathrm{~m}$ were taken. The experiment was laid out in split plot design taking three levels of irrigation viz. Single irrigation at 40 DAP $\left(\mathrm{I}_{1}\right)$, Splash irrigation at 15 days interval $\left(\mathrm{I}_{2}\right)$ and Irrigation at $\mathrm{IW} / \mathrm{CPE}=0.6(\mathrm{IW}=$ $4 \mathrm{~cm})\left(\mathrm{I}_{3}\right)$ in the main plots and three types of mulch management viz. Paddy straw mulch @ 5 t/ha (on dry weight basis) $\left(\mathrm{M}_{1}\right)$, Water hyacinth @ $5 \mathrm{t} / \mathrm{ha}$ (on dry weight basis) $\left(\mathrm{M}_{2}\right)$ and Soil cover (ridge and furrow) $\left(\mathrm{M}_{3}\right)$ in the sub plots. The layout of the experiment was done accordingly during Kharif season i.e. in rice. After harvest of aman paddyscoops were made in the land at desired spacing using a spade and the sprouted whole potato tubers of around $40 \mathrm{gm}$ sizes were planted horizontally so that the root comes in contact with the soil early. The inter row spacing was maintained at $50 \mathrm{~cm}$ and the spacing in-between the tubers was $20 \mathrm{~cm}$. The variety used for planting was Kufri Jyoti. The record on plant emergence was taken randomly from five rows of plot differing in mulching. The plant emergence (\%) was calculated from the observation. To determine the number of haulms per hill five plants were selected randomly from the plot and the number of haulms per hill were counted at 35 DAP and then their average was taken. The plant height was taken by randomly selecting five plants from the plots and then measuring their height with a meter scale at 65 DAP. Plant height indicates the length of the plant from the soil surface to the tip of the plant. The average plant height for each plot was calculated from the observation taken. Two plants each was taken from each plot at 83 DAP. The leaves and the stems were separated and then packed in paper bags and dried at $60^{\circ} \mathrm{C}$ in hot air oven for 24 hours. 
Their average dry weight were recorded and converted into $\mathrm{g} / \mathrm{m}^{2}$ area to get the leaf and stem dry weight. To get the tuber dry weight, five plants were taken from each plot at 83 DAP. The tubers were then collected and cut into small chips. It was then put into paper bags and dried in hot air oven.

Their average dry weight was taken and converted into $\mathrm{g} / \mathrm{m}^{2}$ and $\mathrm{t} / \mathrm{ha}$. Five plants were uprooted randomly from the plots at 65 DAP. For calculating the number of tubers per hill, the number of tubers in each plant was counted and the average was taken.

To get the final potato yield at harvest, the fresh weight of tubers of each plot at harvest was taken in $\mathrm{kg}$ and then it was converted into t/ha. Statistical analysis and interpretation of results was done by calculation values of SEm $( \pm)$ [Standard error of mean] and CD at $5 \%$ [critical difference at $5 \%$ level of significance] as described by Panse and Sukhatme (1978). For comparison of "F" and " $t$ " table values for determination of critical differences, Fisher and Yates table were consulted.

\section{Results and Discussion}

\section{Growth attributes}

\section{Sprouting and emergence}

Potato seed tuber planted in low land rice ecosystem under zero tilled situations with different mulches showed differential sprouting and emergence at weekly interval. Plant emergence was at faster rate in soil cover followed by paddy straw mulch (Table 1). Plant emergence suffered in water hyacinth at early stage but difference in sprouting and emergence due to mulches was narrowed down later i.e. 4 weeks after planting. Jalil et al., (2004), also recorded delay in emergence with straw mulch and water hyacinth mulch.

\section{Plant height}

Potato plant height was not significantly influenced by irrigation levels but mulch types recorded significant differences in plant height (Table 2). Plant height of potato in low land rice ecosystem with zero tillage was very short. Splash irrigation at 15 days interval $\left(\mathrm{I}_{2}\right)$ in low land recorded the maximum plant height $(41.7 \mathrm{~cm})$ followed by single irrigation at 40 days after planting $\left(\mathrm{I}_{1}\right)$. Irrigation at IW/CPE of $0.6\left(\mathrm{I}_{3}\right)$ recorded the lowest plant height of $40.5 \mathrm{~cm}$. Mulches had a significant variation in plant height in zero till potato. Water hyacinth $\left(\mathrm{M}_{2}\right)$ recorded the highest plant height of $45.1 \mathrm{~cm}$ which was at par with paddy straw mulch $\left(\mathrm{M}_{1}\right)(44.3 \mathrm{~cm})$. Plant height was significantly less $(33.8 \mathrm{~cm})$ in potato cultivated with soil cover $\left(\mathrm{M}_{3}\right)$. Similar results were also recorded by Mohammad et al., (2002) and Kar and Kumar (2007).

\section{Number of haulms per hill}

The number of haulms per hill in zero till potato cultivated in low land rice ecosystem was not significantly influenced by irrigation scheduling. In general number of haulms per hill in zero till potato was less and there was no impact of irrigation levels on the number of haulms which varied from 3.1 to 3.3 per hill.

Impact of the mulch materials was also not seen on the haulms per hill (Table 2). In general water hyacinth showed maximum haulms (3.3) and soil cover (3.0) had the least number of haulms.

\section{Total above ground dry matter production}

Above ground dry matter production in ZT potato was not significantly influenced by irrigation levels (Table 2). However maximum above ground dry matter $\left(95.04 \mathrm{~g} / \mathrm{m}^{2}\right)$ was recorded at IW/CPE 0.6 irrigation schedule (I3) and the least dry matter $\left(84.96 \mathrm{~g} / \mathrm{m}^{2}\right)$ was 
produced with irrigation at 40 days after planting $\left(\mathrm{I}_{1}\right)$. Mulch application in ZT potato had a significant influence on above ground DM production (Table 2). Soil cover $\left(\mathrm{M}_{3}\right)$ recorded significantly higher $(10.82 \%)$ over paddy straw or water hyacinth mulch.

\section{Tuber dry matter production}

Sink potential in terms of tuber dry matter production in ZT potato was significantly influenced by irrigation and mulch management practices (Table 2). The highest tuber dry matter accumulation $\left(136.88 \mathrm{~g} / \mathrm{m}^{2}\right)$ was noted with single irrigation (I1) and the least $\left(93.17 \mathrm{~g} / \mathrm{m}^{2}\right)$ was at IW/CPE 0.6 irrigation schedule $\left(\mathrm{I}_{3}\right)$. The dry matter increase in single irrigation was to the tune of $46.91 \%$ over irrigation schedule at IW/CPE $0.6\left(\mathrm{I}_{3}\right)$. Among the mulches, water hyacinth $\left(\mathrm{M}_{2}\right)$ recorded the highest tuber dry matter production $\left(141.63 \mathrm{~g} / \mathrm{m}^{2}\right)$ followed by paddy straw $\left(\mathrm{M}_{1}\right)$ mulch $\left(126.24 \mathrm{~g} / \mathrm{m}^{2}\right)$. Soil cover produced the lowest tuber dry matter $(67.88$ $\mathrm{g} / \mathrm{m}^{2}$. The results are in corroboration with Kar and Kumar (2007) and Dash et al., (2018)

Table.1 Sprouting and emergence count of ZT potato as influenced by mulch types

\begin{tabular}{|l|c|c|c|c|}
\hline \multirow{2}{*}{ Mulch type } & \multicolumn{4}{c|}{ Sprouting and emergence count (\%) at weekly interval } \\
\cline { 2 - 5 } & \multicolumn{1}{|c|}{$\mathbf{1}^{\text {st }}$} & $\mathbf{2}^{\text {nd }}$ & $\mathbf{3}^{\text {rd }}$ & $4^{\text {th }}$ \\
\hline Paddy straw & Greening $(>50 \%)$ & 25 & 63 & 89 \\
\hline Water hyacinth & Greening $(>30 \%)$ & 12 & 38 & 65 \\
\hline Soil cover & Greening $(>60 \%)$ & 35 & 76 & 93 \\
\hline
\end{tabular}

Table. 2 Growth, dry matter production and yield of ZT potato as influenced by irrigation and mulch management in low land rice ecosystem

\begin{tabular}{|c|c|c|c|c|c|c|c|}
\hline \multirow[t]{2}{*}{ Treatment } & \multicolumn{2}{|c|}{ Growth Attributes } & \multicolumn{3}{|c|}{ Dry Matter at Harvest } & \multicolumn{2}{|c|}{ Yield Attributes } \\
\hline & $\begin{array}{c}\text { Haulms/hi } \\
\text { Il }\end{array}$ & $\begin{array}{c}\text { Plant } \\
\text { height } \\
\text { (cm) }\end{array}$ & $\begin{array}{l}\text { Above } \\
\text { ground }\end{array}$ & Tuber & Total & $\begin{array}{c}\text { No of } \\
\text { tubers } \\
\text { /hill }\end{array}$ & $\begin{array}{l}\text { Yield at } \\
\text { harvest } \\
\text { (T/Ha) }\end{array}$ \\
\hline \multicolumn{8}{|l|}{ Irrigation (I) } \\
\hline $\begin{array}{l}I_{1} \text { : Irrigation at } 40 \\
\text { DAP }\end{array}$ & 3.1 & 40.9 & 84.96 & 136.88 & 221.84 & 4.7 & 8.621 \\
\hline $\mathrm{I}_{2}:$ Splash irrigation & 3.2 & 41.7 & 85.35 & 105.69 & 191.04 & 3.9 & 7.139 \\
\hline$I_{3}:$ IW/CPE 0.6 & 3.1 & 40.5 & 95.04 & 93.17 & 188.21 & 4.6 & 7.065 \\
\hline $\operatorname{SEm}( \pm)$ & 0.05 & 0.95 & 2.31 & 3.79 & 7.18 & 0.16 & 0.22 \\
\hline $\mathrm{CD}(\mathrm{P}=0.05)$ & NS & NS & NS & 14.89 & 28.21 & 0.63 & 0.87 \\
\hline \multicolumn{8}{|l|}{ Mulch (M) } \\
\hline$M_{1}$ : Paddy straw & 3.0 & 44.3 & 82.90 & 126.24 & 209.11 & 4.3 & 8.362 \\
\hline $\mathbf{M}_{2}$ : Water hyacinth & 3.3 & 45.1 & 86.55 & 141.63 & 228.18 & 4.1 & 9.639 \\
\hline $\mathrm{M}_{3}$ : Soil cover & 3.0 & 43.8 & 95.92 & 67.88 & 163.79 & 4.8 & 4.824 \\
\hline $\operatorname{SEm}( \pm)$ & 0.09 & 0.85 & 1.43 & 6.94 & 9.00 & 0.10 & 0.34 \\
\hline $\mathrm{CD}(P=0.05)$ & NS & 2.62 & 4.39 & 21.38 & 27.72 & 0.31 & 1.02 \\
\hline
\end{tabular}




\section{Total dry matter production}

Cumulative dry matter accumulation in ZT potato was significantly influenced by irrigation and mulch materials used (Table 2) in low land rice ecosystem. Single irrigation $\left(\mathrm{I}_{1}\right)$ at 40 days recorded the highest dry matter yield $\left(221.84 \mathrm{~g} / \mathrm{m}^{2}\right)$ per unit area which was significantly followed by splash irrigation $\left(\mathrm{I}_{2}\right)$ at 15 days interval $\left(191.04 \mathrm{~g} / \mathrm{m}^{2}\right)$. Irrigation at IW/ CPE $0.6\left(\mathrm{I}_{3}\right)$ gave the lowest dry matter yield $\left(188.21 \mathrm{~g} / \mathrm{m}^{2}\right)$ per unit area. Among the mulches, water hyacinth $\left(\mathrm{M}_{2}\right)$ recorded more dry matter production per unit area $(228.18$ $\left.\mathrm{g} / \mathrm{m}^{2}\right)$ than paddy straw $\left(\mathrm{M}_{1}\right)$. Soil cover $\left(\mathrm{M}_{3}\right)$ had the least $\left(163.79 \mathrm{~g} / \mathrm{m}^{2}\right)$ dry matter yield in zero till potato.

\section{Yield attributes}

\section{Number of tubers per hill}

The number of tubers per hill in ZT potato was significantly influenced by irrigation and mulches used (Table 2). Single irrigation at 40 days $\left(I_{1}\right)$ of crop growth recorded the highest number of tubers (4.7) per hill followed by irrigation applied at IW/CPE 0.6 (4.6) and the least number of tubers (3.9) was recorded at splash irrigation $\left(\mathrm{I}_{2}\right)$ in ZT potato. Mulch management failed to increase the tuber number per hill (4.1-4.3) over soil cover (4.8). Soil cover $\left(\mathrm{M}_{3}\right)$ provides better environment for tuber initiation.

\section{Tuber yield}

The productivity of zero till potato in low land rice ecosystem was significantly influenced by differential soil moisture regime created by irrigation and mulches (Table 2). Fresh tuber yield of potato under no till situation in low land rice ecosystem was very low due to soil-water-nutrient stress environment for potato growth and development. Only single irrigation at 40
DAP $\left(\mathrm{I}_{1}\right)$ recorded the highest tuber yield (8.62 $\mathrm{t} / \mathrm{ha})$ followed by four splash irrigations at 15 days interval $(7.14 \mathrm{t} / \mathrm{ha})$ and irrigation applied two times (22 DAP and 63 DAP) recorded the lowest yield $(7.06 \mathrm{t} / \mathrm{ha})$ due to wide interval of irrigation at peak bulking stage. The application of paddy straw $\left(\mathrm{M}_{1}\right)$ and water hyacinth $\left(\mathrm{M}_{2}\right)$ significantly increased the tuber yield by 73.3-99.8\% over soil cover $\left(\mathrm{M}_{3}\right)$. Among the mulches water hyacinth recorded the highest yield $(9.64 \mathrm{t} / \mathrm{ha})$ followed by paddy straw mulch $(8.36 \mathrm{t} / \mathrm{ha})$. Soil cover gave poor yield (4.82 t/ha) under zero till situation. The mulched crop yielded higher due to the higher level of weed control (39.59-55.79\%) and the ability to reduce excessive water evaporation from the soil (Ashworth and Harrison, 1983; Swenson et al., 2004). Mulched crop recorded better yield attributes compared with soil cover. Beneficial effects of mulches on potato were also reported by Chandra et al., 2002 and Dash et al., 2018.

We may thus conclude from this experiment that single irrigation at 40 DAP gave a good tuber yield of potato in zero till situation. Mulching significantly affected both the growth and yield parameters of potato. Mulches increased the yield by 73.3 to $99.8 \%$ over soil cover thus, the use of mulches may be advocated in potato especially under reduced water supply conditions. Water hyacinth was found to be good mulching material in zero till potato.

\section{References}

Chandra, S., Singh, R.D. Bhatnagar, V.K. and Bisht, J.K. 2002. Effect of mulch and irrigation on tuber size, canopy temperature, water used and yield of potato. Indian Journal of Agronomy 47 (3): 443-448.

Dash, S.N., Y. Pushpavati and Beherea, S. 2018.Effect of irrigation and mulching 
on growth, yield and water use efficiency of potato. Int. J. Curr. Microbiol. App. Sci. 7 (02): 2582-2587.

Jalil, M.A., Azad, M.A.K and Farooque, A.M. 2004. Effect of different mulches on the growth and yield of two potato varieties. Journal of Biological Sci. 4 (3): 331-333.

Kar, G. and Kumar, A. 2007. Effects of irrigation and straw mulch on water use and tuber yield of potato in eastern India. Agril. Water Management. 94 (13): 109-16.
Mohammad, M.M., K. Farooq, A. Hussain and Sher, R. 2002. Effect of mulching on growth and yield of potato crop. Asian J. Pl. Sci. 2: 132-133.

Panse, V.G. and Sukhatme, P.V. (1978).Statistical Methods for Agricultural Workers, Indian Council of Agril. Res. India, 8: 65.

Shekhawat, G.S. and Naik, P.S. (1999). Potato in India, Technical Bulletin No. 1, CPRI, Shimla.

\section{How to cite this article:}

Chettri, P. and Goswami, S.B. 2018. Effect of Crop and Non Crop Mulch Management under Varying Moisture Regimes on The Growth and Yield of Zero Tillage Potato in Rain-fed Low Land Rice Eco System. Int.J.Curr.Microbiol.App.Sci. 7(09): 2334-2339.

doi: https://doi.org/10.20546/ijcmas.2018.709.290 